\title{
SELECTION OF NATIVE FUNGI STRAINS PATHOGENIC TO Vespula germanica (HYMENOPTERA: VESPIDAE)
}

\author{
Selección de aislamientos nativos de hongos patogénicos a Vespula germanica \\ (Hymenoptera: Vespidae)
}

\author{
Loreto Merino $^{1}$ *, Andrés France ${ }^{1}$, y Marcos Gerding ${ }^{1}$
}

\begin{abstract}
A B S T R A C T
The yellowjacket wasp, Vespula germanica F., is considered a serious pest of productive and recreational activities worldwide. A pathogenicity study was carried out with 29 strains of Metarhizium anisopliae and 30 of Beauveria bassiana against worker and male wasps. Wasps of the same age were fed with liquid sugar baits containing $1 \times 10^{8}$ conidia $\mathrm{mL}^{-1}$ suspensions of each strain. The highest mortality and sporulation were obtained with the strains $\mathrm{Qu}-$ B941 and Qu-B933 of Beauveria bassiana, reaching 79 and $95 \%$ mortality for workers and 66 and $73 \%$ for males, respectively. The strains were tested on workers of $V$. germanica with increasing amounts of bait from 0 to $1 \times 10^{8}$ conidia $\mathrm{mL}^{-1}$. The results also showed that $1 \times 10^{8}$ conidia $\mathrm{mL}^{-1}$ increased up to 90 and $97 \%$ the mortality of workers with Qu-B941 and Qu-B933 strains, respectively.
\end{abstract}

Key words: entomopathogens, insect pathology, biological control, yellow jacket.

\section{R E S U M E N}

La avispa chaqueta amarilla, Vespula germanica $\mathrm{F}$. , es una especie cosmopolita, considerada en muchos países como un problema serio para el desarrollo de actividades productivas y recreativas. Entre las nuevas alternativas para el control de la plaga está el uso de hongos entomopatógenos. Se estudió la patogenicidad de 29 aislamientos de Metarhizium anisopliae y 30 de Beauveria bassiana, sobre obreras y machos de la avispa. La evaluación se realizó sobre adultos de igual edad, administrando dosis de $1 \times 10^{8}$ conidia $\mathrm{mL}^{-1}$ de cada aislamiento, en cebos líquidos azucarados. La mortalidad y esporulación de los aislamientos de Beauveria bassiana Qu-B941 y Qu-B933 fueron significativamente mayores, alcanzando porcentajes de mortalidad de 79 y $95 \%$ para obreras y de 66 y $73 \%$ para machos, respectivamente. Estos aislamientos fueron evaluados en cebos con suspensiones crecientes de 0 a $1 \times 10^{8}$ conidia $\mathrm{mL}^{-1}$ sobre obreras de $V$. germanica. Los resultados obtenidos muestran que mayores concentraciones de inóculo incrementan significativamente los índices de mortalidad, alcanzando 90 y 97\% para Qu-B941 y Qu-B933, respectivamente, con la máxima concentración de inóculo.

Palabras clave: entomopatógeno, patología de insectos, control biológico, chaqueta amarilla.

\footnotetext{
${ }^{1}$ Instituto de Investigaciones Agropecuarias, Centro Regional de Investigación Quilamapu, Casilla 426, Chillán, Chile. E-mail:1merino@inia.cl*Corresponding author.

Received: 12 October 2006. Accepted: 20 December 2006.
} 


\section{INTRODUCTION}

The yellow jacket wasp, Vespula germanica $\mathrm{F}$. (Hymenoptera: Vespidae), has colonized Chile since its introduction in 1974 (Peña et al., 1975), with an increase in its population throughout the country (Chiappa, 1986). The species is present in both urban and rural sectors, and is considered a serious problem for productive activities in various areas -forestry, fruit production, cattle-raising, bee-keeping- and even tourism and recreation (D'Adamo et al., 2001; Sackmann et al., 2001). As with other invading species, this wasp has the potential of impacting negatively on the indigenous fauna, thus constituting a threat to the richness of native ecosystems, although the full extent of its impact is not known (Sackmann et al., 2000).

Some of the current control systems for $V$. germanica are based on the use of toxic bait, which only achieve a localized and temporal reduction of workers, and at the same time are potentially dangerous to other insects, mammals and birds (Rose et al., 1999; Sackmann et al., 2001). Problems of chemical residues, which the use of insecticides can generate, has led to the search for alternatives for pest control that are less harmful to the environment, while at the same time being more effective and persistent over time, as are biological controllers, and specifically entomopathogenic fungi (EPF).

There are precedents for the control of social pests with EPF, as in the control of the ant (Acromyrmex octospinosus), where $90 \%$ mortality rates were reached with fungi, with a high degree of horizontal transmission of the pathogen (Kelley-Tunis et al., 1995) and with termites (Reticulitermes flavipes), where complete colonies have been eliminated using bait with entomopathogenes (KelleyTunis et al., 1995; Sánchez et al., 2002). In the case of $V$. germanica, the use of EPF has resulted in good levels of control with the species Aspergillus flavus (Glare et al., 1996), Beauveria bassiana (Bals.) Voill. (Harcourt et al., 1997) and Metarhizium anisopliae var. anisopliae (Metschnicoff) (Rose et $a l .$, 1999). There is a collection of strains of $B$. bassiana and M. anisopliae in Chile, collected from different agro-systems of the country (France et al., 2000), and thus adapted to national conditions.

The advantage of control with EPF, selected for a determined pest, is that they to have the potential to reduce the pest without affecting native fauna or the environment, which is particularly important given that in this case it is a cosmopolitan pest that is found in both rural and urban areas (Donovan, 1996). EPF are a promising option, provided that the death of the worker wasp does not occur immediately, and can transmit the fungus to the larvae, succeeding in this way to control the complete colony. As well, the sporulation of the fungus in the insect cadavers results in a new source of infection for the insect offspring (Harcourt et al., 1998).

The objectives of this research were to determine the pathogenicity and lethal concentration for $90 \%$ of the population $\left(\mathrm{CL}_{90}\right)$ of native strains of the EPF Beauveria bassiana and Metarhizium anisopliae for control of $V$. germanica.

\section{MATERIALS AND METHODS}

\section{Collection of biological material}

To obtain the insects, live nests of $V$. germanica were collected in the Las Trancas sector of the Pinto commune, Region of Bío-Bío ( $40^{\circ} 25^{\prime} \mathrm{S}, 73^{\circ} 01^{\prime} \mathrm{W}$ ), Chile, during December and January, 2002. The insects were rendered unconscious through the application of $\mathrm{CO}_{2}$ and were taken to the biological control laboratory of the Agricultural Research Institute (INIA), Quilamapu Regional Research Center (CRI), Chillán. Prior to the application of $\mathrm{CO}_{2}$, in the laboratory the adults were separated by castes and the hive floors were prepared, eliminating the eggs and larvae and conserving only the cells with operculated pupae, which were counted and marked. These floors were located in darkness at a temperature of $26 \pm 2{ }^{\circ} \mathrm{C}$. The emerging wasps were collected daily, transferred to growing cages where they were separated into groups of the same caste and age, and fed with a concentrate of $50 \%$ water $/ 50 \%$ honey. The wasps were maintained there at $25 \pm 2{ }^{\circ} \mathrm{C}$ for a week prior to initiating the pathogenicity tests (Butt and Goettel, 2000).

\section{Multiplication of the strains}

The EPF isolates were obtained from the collection belonging to the Insect Pathology Program of the Technological Center of Biological Control of INIA-Quilamapu (France et al., 2000). Fifty-nine strains were selected, which were cultured in Petri dishes with potato dextrose agar. The strains were 
incubated in darkness at $25^{\circ} \mathrm{C}$ for approximately 20 days, until sporulation of the fungus was observed. Subsequently, each strain was multiplied on sterilized rice, from which the conidia were extracted through a sifting process. Each strain was vacuum sealed and kept in darkness at $10{ }^{\circ} \mathrm{C}$ until its use.

\section{Bioassay}

Fifty-nine strains of EPF were evaluated, of which 29 correspond to the fungus $M$. anisopliae (Qu-M) and 30 to B. bassiana (Qu-B). The conidia of these strains were given to the wasps in doses of $1 \times 10^{8}$ spores $\mathrm{mL}^{-1}$ incorporated in a liquid bait of sterile honey and distilled water in a proportion of 30:70 $\mathrm{v} / \mathrm{v}$. The tests were carried out with workers and males of $V$. germanica, for which glass cages of 20 $\mathrm{cm}^{3}$ were used. Ten wasps of the same age and caste were placed in the cages and fed daily with $10 \mathrm{~mL}$ of a liquid bait of water and honey with EPF. The control treatment was carried out with the same bait, but without the EPF.

Mortality and sporulation of the fungus in the dead insects were evaluated daily; the criterion of mortality used was to consider dead those adults that presented neither movement nor the capacity to react. Dead insects were incubated in individual humid chambers at $18{ }^{\circ} \mathrm{C}$, to observe development of mycelium and conidia of EPF.

The experimental design was completely randomized, with six replicates per strain and 10 wasps for each experimental unit. The results obtained were compared through dispersion of mortality and sporulation analyses for each strain, for both worker and male wasps of $V$. germanica. The stocks that reached mortality indices greater than 90 percentile $\left(\mathrm{P}_{90}\right)$ were selected for $\mathrm{CL}_{90}$ studies.

\section{Studies of lethal concentrations $\left(\mathrm{CL}_{90}\right)$}

The strains selected from the pathogenicity test that presented the highest mortality and sporulation indices were multiplied following the previously described methodology. Suspensions were prepared of $0,10^{5}, 10^{6}, 10^{7}$ and $10^{8}$ conidia $\mathrm{mL}^{-1}$ incorporated into liquid bait with a base of sterile honey and distilled water in a proportion of $30: 70 \mathrm{v} / \mathrm{v}$. The tests were carried out on workers of $V$. germanica of the same age; 10 worker wasps were placed in the cages previously described. These were fed daily with $10 \mathrm{~mL}$ of liquid bait. The insect mortality and sporulation of the dead insects were evaluated daily, through incubation in individual humid chambers at $18{ }^{\circ} \mathrm{C}$, to determinate the moment of development of mycelium and conidia of the EPF.

It was used a completely randomized design, with six replicates per strain and 10 wasps per experimental unit. The evaluation of the percentage of mortality for different inoculum concentrations was carried out when the first treatment reached $100 \%$ mortality. The results obtained were compared daily among concentrations and at the end of the test by a variance analysis and separation of means through the Tukey test $(\mathrm{P} \leq 0.05)$ (Gomez and Gomez, 1984). The mortality curve at different concentrations of the selected strains was adjusted to a sigmoid, whose adjustment quality was tested with the chi square test. Subsequently, the curve was linearized through the Probit transformation, assuming normality of the results, to calculate $\mathrm{CL}_{90}$ from the regression equation (Alves, 1998).

\section{RESULTS AND DISCUSSION}

\section{Bioassay}

The results showed different degrees of pathogenic activity on $V$. germanica of the evaluated stock. The evaluation of 30 strains of $B$. bassiana in workers showed that 25 caused some degree of mortality, and of these only two exceeded the $\mathrm{P}_{90}, \mathrm{Qu}-\mathrm{B} 491$ and Qu-B933, which presented the highest percentages of mortality, reaching 95 and $79 \%$, respectively, which was statistically different from the control group $(P=0.005)$. The wasps without EPF did not present any mortality during the period of the test (Figure 1). The evaluations of workers with M. anisopliae showed that of 29 strains evaluated, 18 showed pathogenicity, but in general less than that reached by the strains of B. bassiana. Only the strain Qu-M984 exceeded the $\mathrm{P}_{90}$ of mortality, with $65 \%$ (Figure 1).

The results of feeding with $B$. bassiana in males of $V$. germanica showed that 27 strains provoked mortality, and as in the case of the workers, the strains Qu-B941 and Qu-B900 exceeded the $\mathrm{P}_{90}$, with percentages of 73 and $66 \%$, respectively (Figure $2 \mathrm{~A}$ ). The 18 strains of $M$. anisopliae produced mortalities, but only the strain Qu-M 984 exceeded the $\mathrm{P}_{90}$ of mortality, with 66\% (Figure 2B). 

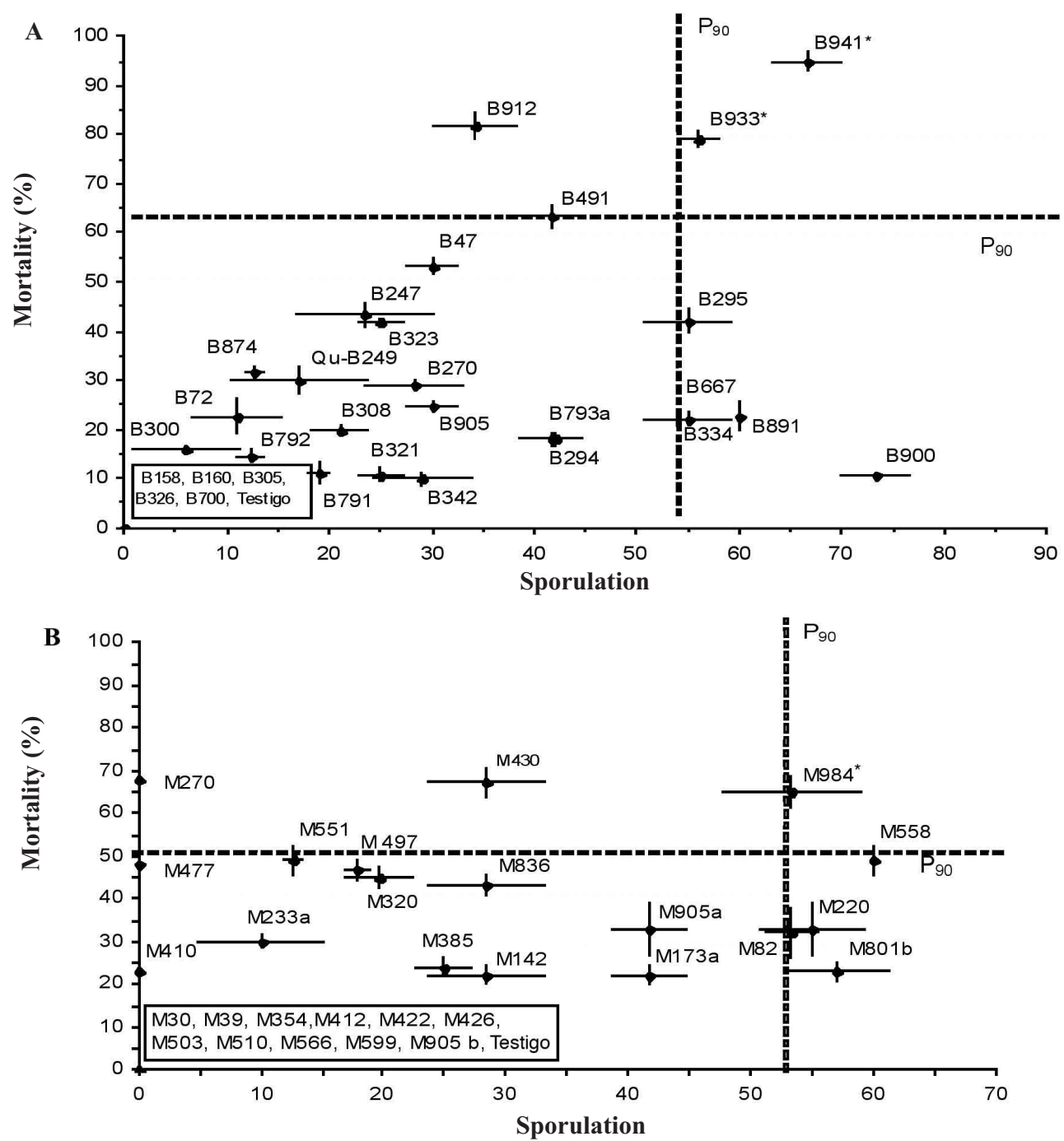

Figure 1. Mortality and production of conidia on Vespula germanica workers inoculated with native strains of Beauveria bassiana (A) and Metarhizium anisopliae (B).

Figura 1. Mortalidad y esporulación en obreras de Vespula germanica inoculadas con cepas nativas de Beauveria bassiana (A) y Metarhizium anisopliae (B).

*Values exceeding $\mathrm{P}_{90}$ for mortality and sporulation.

Horizontal and vertical bars for each observation indicate significant differences for sporulation and mortality according to Tukey's test $(\mathrm{P}<0.05)$.

There was not a proportional relationship between percentages of mortality and sporulation, which coincides with what is observed with other species of insects (Rodríguez et al., 2006). The strains of $B$. bassiana showed greater sporulation capacity on the wasp cadavers than those of $M$. anisopliae, reaching levels of 77 and $67 \%$ with the strains QuB900 and Qu-B933, respectively. On the other hand, with $M$. anisopliae, the strain Qu-M558 presented the highest percentage of sporulation, with $61 \%$ in workers. The differences in the degree of pathogenicity among stocks belonging to the same species of fungus can be attributed to genetic variations given by the specificity for a determined host and different geographic origins (Coates et al., 2002; Rodríguez et al., 2006).

The data on daily mortality rates caused by $B$. bassiana during the 20 days of the test, determined that for the average of replicates, the insects died between a range of 5.4 and 9.3 days post-inoculation, with an average survival of 7.65 days. In the case of $M$. anisopliae, the average of the replicates was between 4.4 and 7.4 days post-inoculation, with 

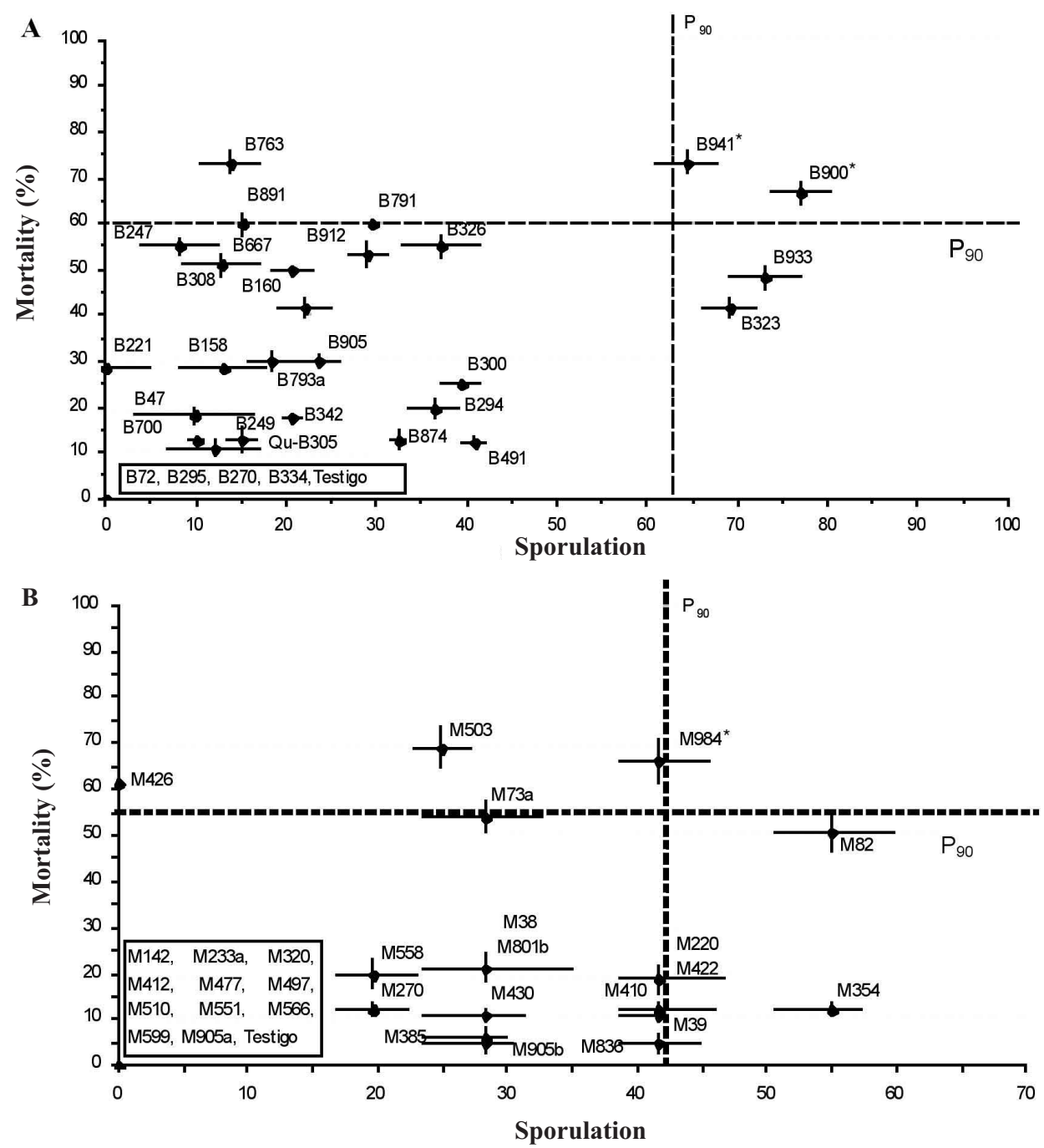

Figure 2. Mortality and conidia productions on Vespula germanica males inoculated with native strains of Beauveria bassiana (A) and Metarhizium anisopliae (B).

Figura 2. Mortalidad y esporulación en machos de Vespula germanica inoculados con cepas nativas de Beauveria bassiana (A) y Metarhizium anisopliae (B).

*Values exceeding $\mathrm{P}_{90}$ for mortality and sporulation.

Horizontal and vertical bars for each observation indicate significant differences for sporulation and mortality according to Tukey's test $(\mathrm{P}<0.05)$.

the average survival time being 5.55 days. The former is relevant given that this treatment is intended to control a social insect where the colony can reject individuals showing symptoms or signs of sickness. This means that delayed-action mortality allows the infected wasp to act as a vector of the fungus, while it continues in incubation, transmitting the infection horizontally and increasing infection time (Ayasse and Paxton, 2002).

Entomopathogenic fungi have the capacity to produce toxins that act as inhibitors of the host's de- fensive reactions, destroying the hemolymph and nucleus of the cells; in addition to a reduction of energy because of utilization of nutrients of the hemolymph by the fungus, which increases until causing the immobility of the insect (Alves, 1998; Harris et al., 2000; Lecuona, 2004). This is of particular relevance, if we consider the complex organization of these insects, based on a system of close collaboration and dependence for the maintenance and development of their colonies (Ayasse and Paxton, 2002). 


\section{Studies of lethal concentrations $\left(C L_{90}\right)$}

The different concentrations of the selected strains were compared on day 11 after the beginning of the test for Qu-B933, and on day 12 for Qu-B941, corresponding to the period in which the strains reached $100 \%$ of mortality. Both strains showed a lineal tendency for mortality, which was directly proportional to the concentration of the inoculum.

Comparing daily mortality of different inoculum concentrations, it was found that the mortality rate of wasps for the strain Qu-B941 began on day 4 post-inoculation with the concentration of $10^{8}$ conidia $\mathrm{mL}^{-1}$ and continued until the end of the evaluation; the concentrations of $10^{7}$ and $10^{8}$ conidia $\mathrm{mL}^{-1}$ were statistically equal to each other, but different $(\mathrm{P}<0.05)$ from the lowest concentrations, both reaching the maximum mortality on day 13 (Figure 3A). With the strain Qu-B933, mortality began on day 3 employing $10^{7}$ conidia $\mathrm{mL}^{-1}$, a concentration that maintained a greater percentage of mortality until day 5 , when it became statistically
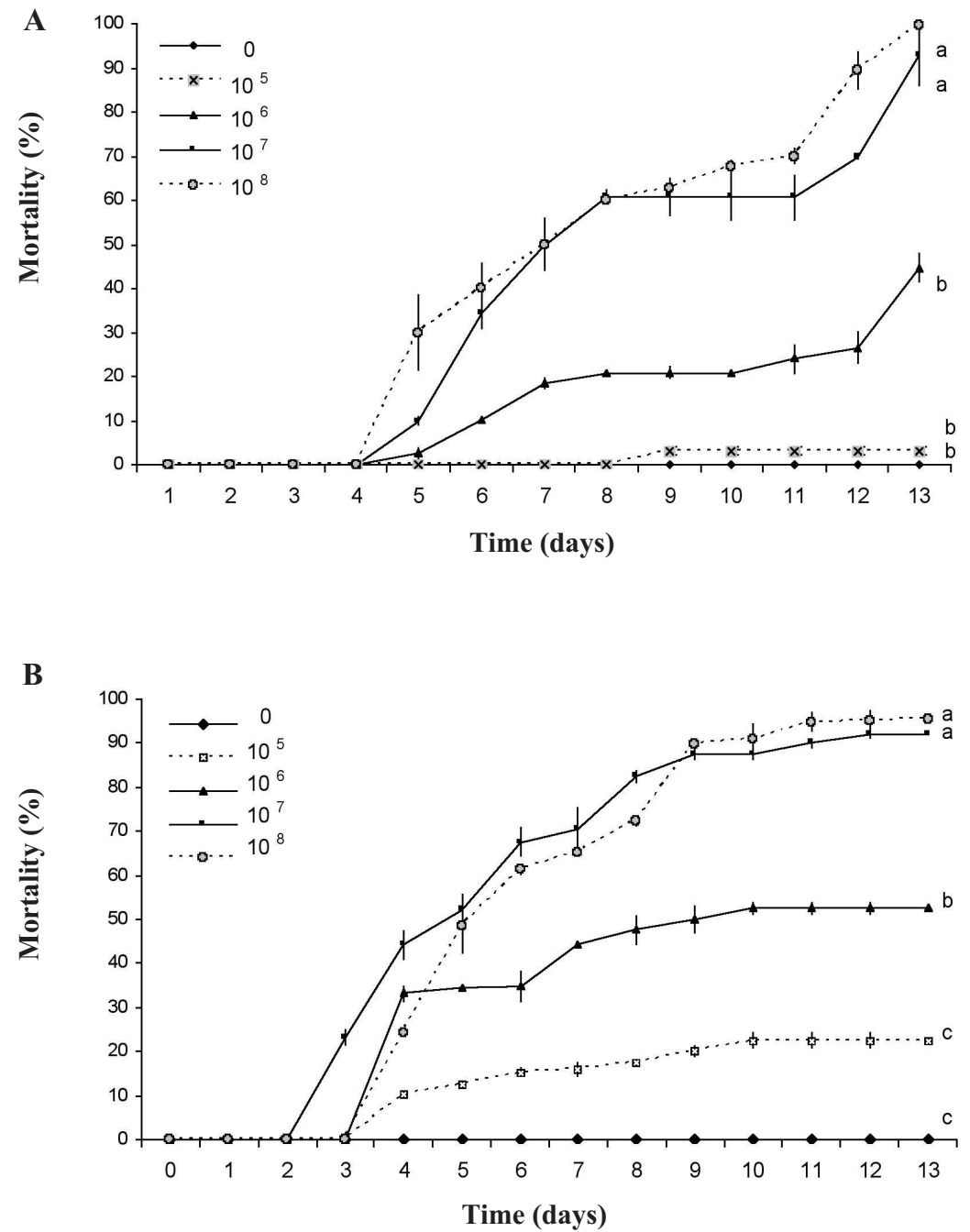

Figure 3. Mortality of Vespula germanica workers inoculated with different concentrations of strains Qu-B941 (A) and Qu-B933 (B) of Beauveria bassiana.

Figura 3. Mortalidad de obreras de Vespula germanica inoculadas con diferentes concentraciones de las cepas Qu-B941 (A) y Qu-B933 (B) de Beauveria bassiana.

Different letters indicate significant differences on area under the curve of mortality progress according to Tukey's test $(\mathrm{P} \leq 0.05)$. 
equal to that of $10^{8}$ conidia $\mathrm{mL}^{-1}$. Beginning at this point and until the end of the test, the percentages of daily mortality for both concentrations were significantly higher than the rest, achieving maximum mortality on day 11 (Figure 3B).

Comparing the accumulated mortality at day 13 for the selected strains, it was observed that in both strains the highest percentages of mortality were reached with doses of $10^{7}$ and $10^{8}$ conidia $\mathrm{mL}^{-1}$, for Qu-B933 and Qu-B941, respectively. With these concentrations, the mortality was statistically equal $(P \leq 0.05)$. A $100 \%$ of mortality rate was achieved with the strain Qu-B941 on day 13, and mortality rates reached with the concentrations of $10^{5}$ and $10^{6}$ conidia $\mathrm{mL}^{-1}$ were statistically equal to control group and were the lowest rates in the test (Figure 3). The Probit transformation provided the straight line equation for Qu-B941: $\mathrm{y}=0.55+$ $3.7\left(\mathrm{R}^{2}=0.93\right)$ and for Qu-B933: $\mathrm{y}=0.57+2.67$

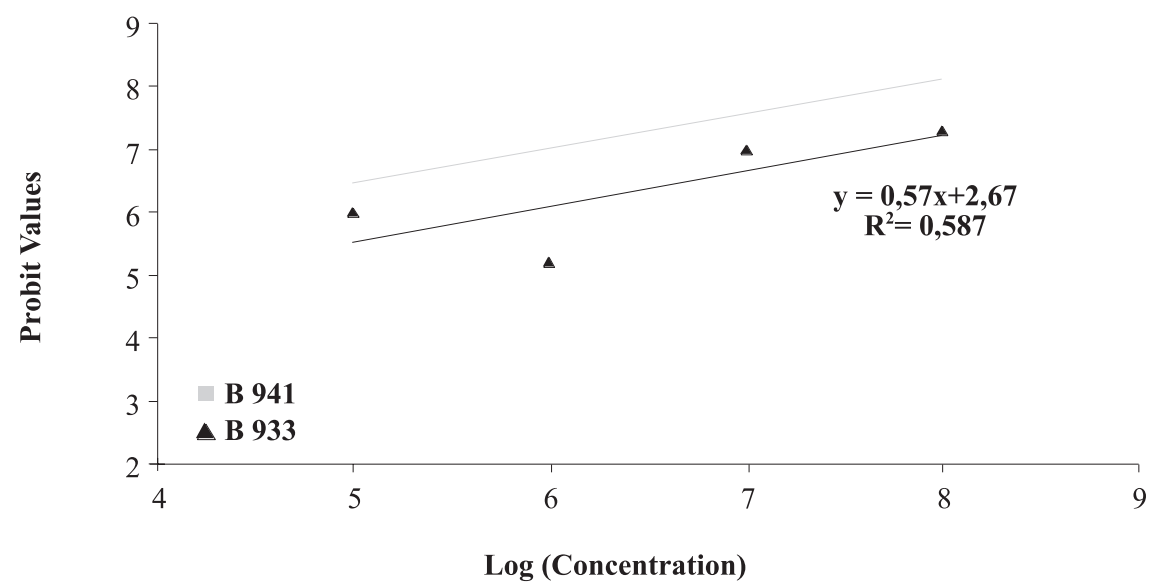

Figure 4. Probit regression for the mortality of Vespula germanica workers inoculated with different concentrations of Beauveria bassiana strains Qu-B941 and Qu-B933.

Figura 4. Regresión Probit para mortalidad de obreras de Vespula germanica inoculadas con diferentes concentraciones de las cepas Qu-B941 y Qu-B933 de Beauveria bassiana.

$\left(\mathrm{R}^{2}=0.59\right)$. Using these equations, the values of $\mathrm{CL}_{90}$ of $1 \times 10^{7.2}$ conidia $\mathrm{mL}^{-1}$ for Qu-B941, and 1 x $10^{6.8}$ conidia $\mathrm{mL}^{-1}$ for Qu-B933 (Figure 4) were obtained.

\section{CONCLUSIONS}

Evaluations in laboratory conditions determined that the strains Qu-B933 and Qu-B941 of the entomopathogenic fungus $B$. bassiana were pathogenic for workers and males of Vespula germanica, reaching percentages of mortality and sporulation higher than 90 and $70 \%$, respectively. For both strains it was established that concentrations of inoculum greater than $10^{7}$ and $10^{8}$ conidia $\mathrm{mL}^{-1}$, respectively, were necessary to cause the mortality of $90 \%$ of the population.

\section{ACKNOWLEDGEMENTS}

This research was carried out with funding from INNOVA Bío-Bío in the framework of the project: Control of Yellow Jacket Wasps: Development and Application of Selective Biological Insecticides. Agreement between Controladora de Plagas Forestales S.A. and INIA Quilamapu. 


\section{LITERATURE CITED}

Alves, S.B. 1998. Fungos entomopatogenicos. p. 289-370. In S.B. Alves (ed.). Controle microbiano de insetos. Fundação de Estudos Agrários Luiz de Queiroz (FEALQ), Piracicaba, Sao Paulo, Brasil.

Ayasse, M., and R. Paxton. 2002. Brood protection in social insects. p. 117-148. In Hilker, M. and T. Meiners (eds.). Chemoecology of insect eggs and egg deposition. Blackwell, Berlin, Germany.

Butt, T.M., and M.S. Goettel. 2000. Bioassays of entomogenous fungi. p. 141-196. In Navon, A. and K.R. Ascher (eds.). Bioassays of entomopathogenic microbes and nematodes. CAB International, Wallingford, UK.

Chiappa, E. 1986. Observaciones sobre el nido de Vespula germanica (F.) (Hymenoptera: Vespidae), en la zona central de Chile. Rev. Chil. Entomol. 13:85-94.

Coates, B., R. Hellmich, and L. Lewis. 2002. Allelic variation of Beauveria bassiana (Ascomycota: Hypocreales) minisatellite is independent of host range and geographic origin. Genome 45:125-132.

D'Adamo, P., J.C. Corley, and M. Lozada. 2001. Attraction of Vespula germanica (Hymenoptera: Vespidae) foragers by conspecific heads. J. Econ. Entomol. 94:850-852.

Donovan, B. 1996. Progress with biological control of wasp. New Zealand Beekeeper 3(4):14-15.

France, A., M.E. Gerding, M. Gerding, y A. Sandoval. 2000. Patogenicidad de una colección de cepas nativas de Metarhizium spp. y Beauveria spp. en Aegorhinus superciliosus, Asynonychus cervinus y Otiorhynchus sulcatus. Agric. Téc. (Chile) 60:189194.

Glare, T., R. Harris, and B. Donovan. 1996. Aspergillus flavus as a pathogen of wasps, Vespula spp., in New Zealand. N.Z. J. Zool. 23:339-344.

Gomez, K., and A. Gomez. 1984. Statistical procedures for agricultural research. 680 p. Wiley \& Sons, New York, USA.

Harcourt, S.J., R.J. Harris, E.A.F Rose, T.R. Glare, and T.L. Nelson. 1997. The potential of Beauveria bassiana for the control of common and German wasp (Vespula vulgaris L. and Vespula germanica F.) in New Zealand. p. 159-164. In O'Callaghan, M.O., and T.A. Jackson (eds.). Proceedings of the $4^{\text {th }}$ International Workshop on Microbial Control of Soil Dwelling Pest. Lincoln, New Zealand. 17-19 February 1997. Microbial Control Group, AgResearch, Lincoln, Canterbury, New Zealand.
Harris, R.J., S.J. Harcourt, T.R. Glare, E.A.F. Rose, and T.L. Nelson. 2000. Susceptibility of Vespula vulgaris (Hymenoptera: Vespidae) to generalist entomopathogenic fungi and their potential for wasp control. J. Invertebr. Pathol. 75:251-258.

Kelley-Tunis, K.K., B.L. Reid, and M. Andis. 1995. Activity of entomopathogenic fungi in free-foraging workers of Camponotus pennsylvanicus (Hymenoptera: Formicidae). J. Econ. Entomol. 88:937-943.

Lecuona, R. 2004. Bioinsumos. Una contribución a la agricultura sustentable. 58 p. INTA, Buenos Aires, Argentina.

Peña, L., R. Pérez de Arce, y L. Cartagena. 1975. La presencia de Vespula maculifrons (Buyssoni), (Hymenoptea: Vespidae) en Chile. Rev. Chil. Entomol. 9:167-168.

Rodríguez, M., M.E. Gerding, y A. France. 2006. Selección de aislamientos de hongos entomopatógenos para el control de la polilla del tomate (Tuta absoluta Meyrick) (Lepidoptera: Gelechiidae). Agric. Téc. (Chile) 66:159-165.

Rose, E., R. Harris, and T. Glare. 1999. Possible pathogens of social wasp (Hymenoptera: Vespidae) and their potential as biological control agents. N.Z. J. Zool. 26:179-190.

Sackmann, P., P. D’Adamo, M. Rabinovich, and J. Corley. 2000. Arthropod prey foraged by the German wasp (Vespula germanica) in NW Patagonia, Argentina. N.Z. Entomol. 23:55-59.

Sackmann, P., M. Rabinovich, and J. Corley. 2001. Successful removal of German yellowjacket (Hymenoptera: Vespidae) by toxic baiting. J. Econ. Entomol. 94:811-816.

Sánchez, P., F. Morillo, F. Caetano, T. Iturriaga, J. Guerra, and W. Muñoz. 2002. Detección de hongos entomopatógenos del género Cordyceps ((Fr.) Link), 1833 (Ascomycotina: Pyrenomycetes) sobre hormigas del género Camponotus Mayr, 1861 (Hymenoptera: Formicidae) en plantaciones de cacao de Barlovento, Estado de Miranda, Venezuela. Entomotropica 17:191-195. 